\title{
ОЦЕНКА ЭФФЕКТИВНОСТИ ИСПОЛЬЗОВАНИЯ АНТИБИОТИКА АМИНОГЛИКОЗИДНОГО РЯДА ПРИ ЛЕЧЕНИИ КАРИЕСА
}

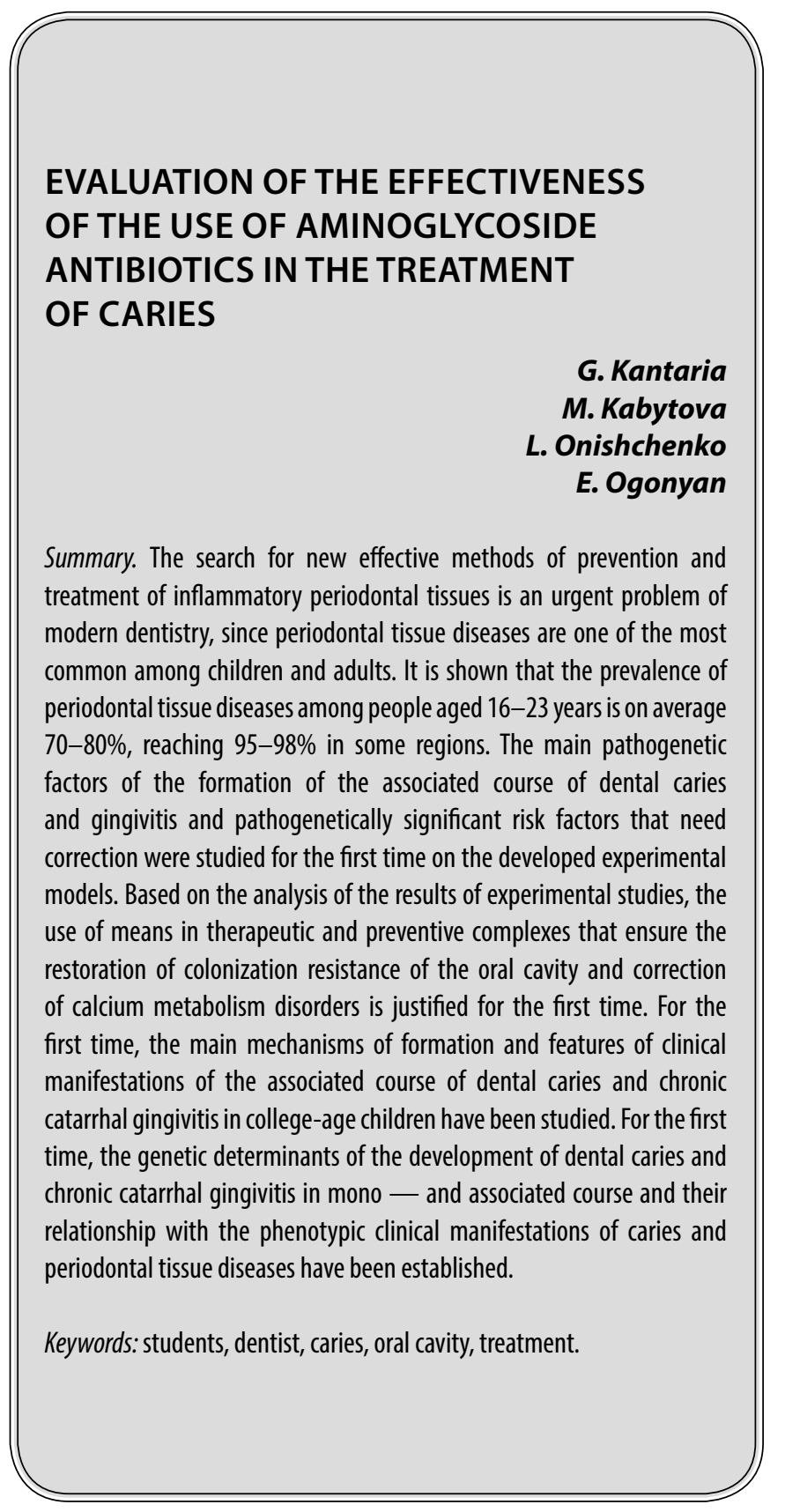

B ходе экспериментальных исследований разработан способ воспроизведения кариеса на экспериментальной модели крыс путем применения сбалансированной КГД и дополнительного воздействия антибиотика аминогликозидного ряда гентамицина [5] в бактериостатической концентрации [6], к которому микроорганизмы группы стрептококков мало чувстви-
Кантария Гваниа Отариевна

ФГБОУ ВО «Волгоградский государственный медицинский университет» gvantsa_15@mail.ru

Кабытова Мария Викторовна

К.м.н., Ассистент, ФГБОУ ВО «Волгоградский государственный медицинский университет» mashan.hoi@mail.ru

Онищенко Любовь Федоровна

К.м.Н., дочент, ФГБОУ ВО «Волгоградский государственный медицинский университет» onishchenko_If@mail.ru

Огонян Елена Александровна

К.м.н., дочент, ФГБОУ ВО «Волгоградский государственный медицинский университет»

ogonyan111@mail.ru

Аннотация. Поиск новых эффективных методов профилактики и лечения воспалительных тканей пародонта является актуальной проблемой современной стоматологии, поскольку заболевания тканей пародонта являются одним из самых распространенных среди детского так и взрослого населения. Показано, что распространенность заболеваний тканей пародонта среди людей в возрасте 16-23 лет составляет в среднем 70-80\%, достигая в отдельных регионах 95-98\%. На разработанных экспериментальных моделях впервые проведено изучение основных патогенетических факторов формирования ассоциированного течения кариеса зубов и гингивита и патогенетически значимых факторов риска, которые нуждаются в коррекции. На основании анализа результатов экспериментальных исследований впервые обосновано использование в лечебно-профилактических комплексах средств, обеспечивающих восстановление колонизационной резистентности полости рта и коррекцию нарушений метаболизма кальция. Впервые изучены основные механизмы формирования и особенности клинических проявлений ассоциированного течения кариеса зубов и хронического катарального гингивита у детей студенческого возраста. Впервые установлены генетические детерминанты развития кариеса зубов и хронического катарального гингивита при моно — и ассоциированном течении и их взаимосвязь с фенотипическими клиническими проявлениями кариеса и заболеваний тканей пародонта.

Ключевые слова: студенты, врач-стоматолог, кариес, полость рта, лечение.

тельны [1]. Предложенная КГМ обоснована на I этапе исследований с участием крыс в трех группах. Крысы 1 группы (контрольная, $\mathrm{n}=10$ ), средний вес $55,0 \pm 0,83$ г, находились на пищевом режиме вивария. У крыс 2 группы

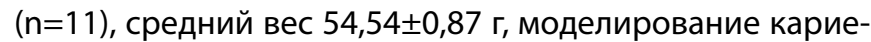
са зубов осуществляли по кариесогенной диете Стефана.

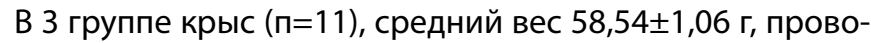


Таблица 1. Показатели кариозного поражения зубов у крыс

\begin{tabular}{|l|l|l|l|}
$\begin{array}{l}\text { Показатель } \\
\text { Группа }\end{array}$ & $\begin{array}{l}\text { Количество кариозных зубов, } \\
\text { среднее на 1 крысу }\end{array}$ & $\begin{array}{l}\text { Количество кариозных } \\
\text { поражений, среднее на 1 } \\
\text { крысу }\end{array}$ & $\begin{array}{l}\text { Глубина кариозных } \\
\text { поражений (баллы) }\end{array}$ \\
\hline 1 группа, п=10 & $2,30 \pm 0,15$ & $3,60 \pm 0,13$ & $1,11 \pm 0,05$ \\
\hline 2 группа, п=9 & $4,45 \pm 0,15$ & $9,45 \pm 0,17$ & $1,57 \pm 0,08<$ \\
\hline 3 группа, п=9 & $4,67 \pm 0,14$ & $8,89 \pm 0,16$ & $1,91 \pm 0,09$ \\
\hline
\end{tabular}

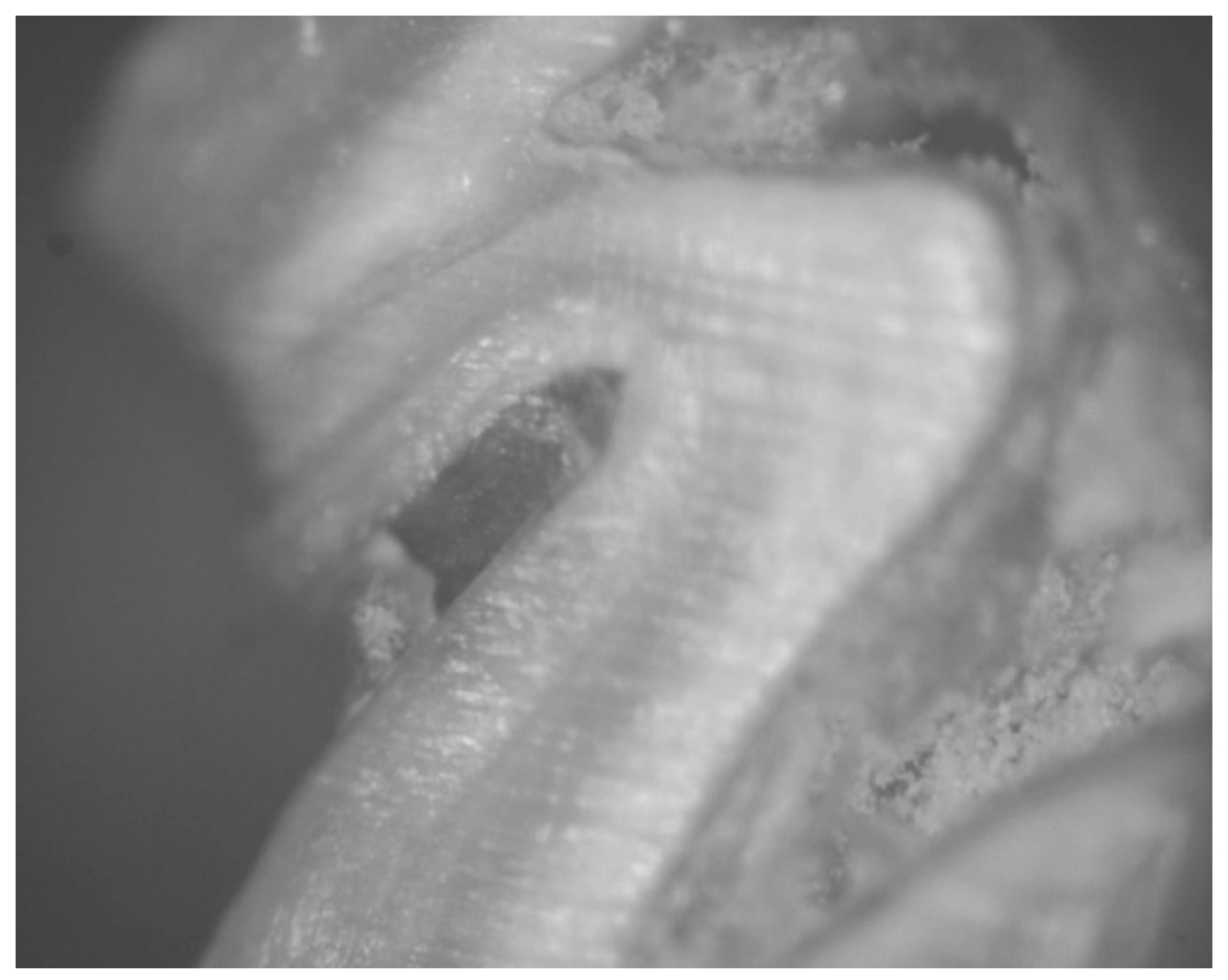

Рис. 1. Фиссура третьего нижнего моляра, невредимая кариозным процессом, у крысы и группы (0 баллов)

дили воспроизведение КГМ по разработанному способу. Вода для крыс в виварии была постоянно в свободном доступе [2]. Внешний вид всех животных, отобранных для проведения исследований, нос розового цвета, глаза ясные, блестящие, шершавая белая, гладкая, поведение активное, мочевыделение в норме, аппетит хороший, груминг активный.

Крысы находились под постоянным наблюдением [7], оценивали их внешний вид, двигательную активность и груминг, что является показателями состояния и поведения крыс [4]. Во время проведения экспериментальных исследований наблюдали изменения внешнего вида (шероховатая влага, облысение на голове, наличие раздражений на хвосте) и поведения (заторможенность, аппетит снижен - вес набирают плохо, мочеотделение повышено, груминг частый, короткий) четырех животных, из которых две крысы 2 группы, где воспроизводили экспериментальный кариес по модели Стефана, и две крысы 3 группы, где воспроизводили кариес по разработанной КГМ, в дальнейшем погибли [3]. Другие крысы этих групп в конце эксперимента имели незначительное повышение мочевыделения в связи с повышенным употреблением воды. У крыс и группы (контрольной) изменений в поведении и состоянии в течение всего эксперимента не наблюдали.

В последний день удержания определяли вес животных: крысы 1 группы $(\mathrm{n}=10)$ имели средний вес 103,25 66,86 г, крысы 2 группы $(n=9)-88,56 \pm 4,33$ г, крысы 3 группы (n=9) - 85,44+4,01 г. Это свидетельствует, что крысы, получавших кариесогенный рацион, набирали вес хуже, чем крысы контрольной группы. 


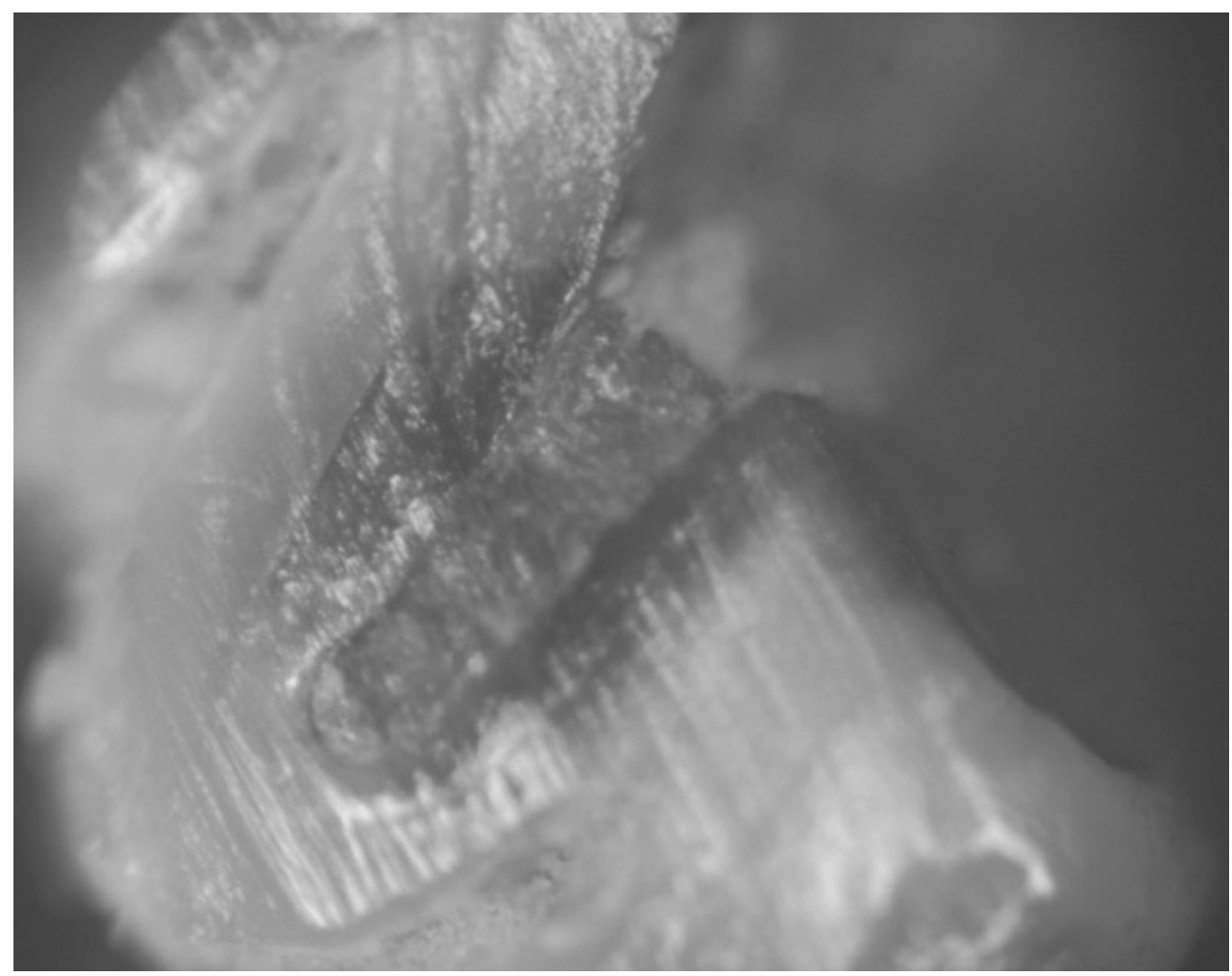

Рис. 2. Фиссура второго моляра нижней челюсти крысы 2 группы. Наблюдается проникновение азотнокислого серебра в пределах всей эмали (2 балла)

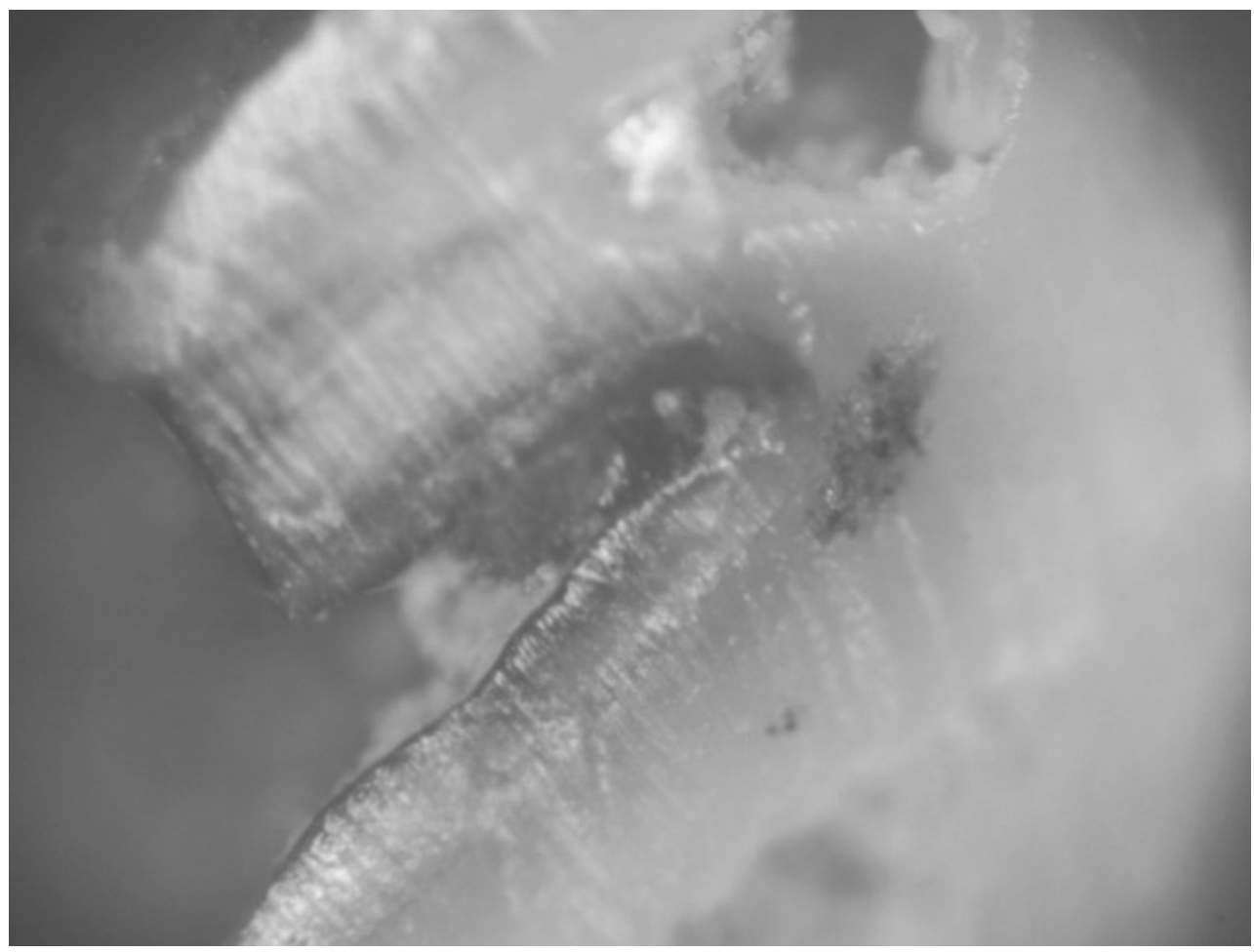

Рис. 3. Фиссура третьего моляра верхней челюсти крысы 3 группы. Наблюдается проникновение азотнокислого серебра по эмалево-дентинному соединению (3 балла) 
Таблица 2. Биохимические показатели крови крыс

\begin{tabular}{|l|l|l|l|}
$\begin{array}{l}\text { Показатель } \\
\text { Группа }\end{array}$ & $\begin{array}{l}\text { Крысы 1 (контрольной) } \\
\text { группы (п=10) }\end{array}$ & Крысы 2 группы (п=9) & Крысы 3 группы (п=9) \\
\hline Сахар (ммоль/л) & $7,48 \pm 0,25$ & $7,05 \pm 0,21$ & $6,88 \pm 0,21$ \\
\hline Р (ммоль/л) & $2,35 \pm 0,11^{*}$ & $2,09 \pm 0,09$ & $1,99 \pm 0,11$ \\
\hline Са (ммОль/л) & $3,03 \pm 0,24^{*}$ & $2,39 \pm 0,15$ & $2,18 \pm 0,06$ \\
\hline ЛФ (О/л) & $140,31 \pm 10,65^{*}$ & $148,21 \pm 6,334$ & $169,84 \pm 5,14$ \\
\hline КФ (О/л) & $2,70 \pm 0,04^{*}$ & $3,60 \pm 0,154$ & $5,13 \pm 0,20$ \\
\hline ЛФ/КФ & $51,62 \pm 3,28^{*}$ & $41,19 \pm 0,73<$ & $33,71 \pm 2,01$ \\
\hline АСТ (О/л) & $113,06 \pm 4,25^{*}$ & $145,71 \pm 5,834$ & $184,37 \pm 3,95$ \\
\hline АЛТ (О/л) & $66,97 \pm 1,94^{*}$ & $85,63 \pm 3,53$ & $86,47 \pm 4,11$ \\
\hline МДА (мкмоль/л) & $1,55 \pm 0,05^{*}$ & $3,35 \pm 0,19$ & $3,60 \pm 0,25$ \\
\hline Каталаза (\%) & $78,73 \pm 1,76^{*}$ & $58,43 \pm 1,71$ & $60,78 \pm 1,98$ \\
\hline АПИ & 50,79 & 17,44 & 16,88 \\
\hline
\end{tabular}

Примечания:

* - p<0,05 - достоверность различия между показателями 1 и 2, 3 групп;

- - $\mathrm{p}<0,05$ - достоверность различия между показателями 2 и 3 групп.

Результаты экспериментальных исследований свидетельствуют, что при воспроизведении кариеса по разработанной КГМ (3 группа) и по модели Стефана (2 группа) у $100 \%$ крыс 2-месячного возраста возникает кариес зубов, что проявляется деминерализацией эмали и дентина и наличием кариозных поражений. У крыс 1 (контрольной) группы наличие признаков деминерализации эмали наблюдали лишь в 30\% случаев. Оценка интенсивности поражения кариесом по гистохимическим методом Колесника А.Г. (1974) показала, что по количеству кариозных поражений и кариозных зубов на одной крысы животные 2 и 3 групп достоверно отличаются от крыс 1 (контрольной) группы, находившихся на рационе вивария, но между собой не имеют достоверной разногласия\& Обращает на себя внимание тот факт, что по показателю глубины кариозных поражений эти группы имеют достоверные различия между собой, то есть использование КГМ с учетом двух основных факторов развития кариеса зубов (употребление углеводов и избыточный рост микроорганизмов) ускоряет развитие кариеса зубов у крыс (табл. 1).

Фото под люминесцентным микроскопом демонстрируют глубину проникновения ионов азотнокислого серебра в твердые ткани зубов крыс в исследуемых группах (рис. 1, 2, 3).

Биохимическое исследование сыворотки крови показало при отсутствии клинико-лабораторных признаков сахарного диабета (содержание сахара в крови

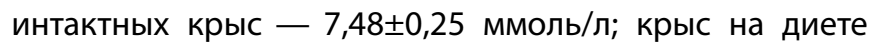

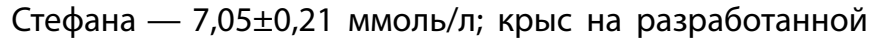

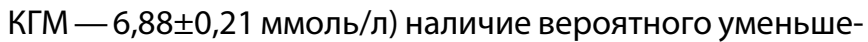
ния содержания Р и Са у крыс 2 и 3 групп по сравнению с крысами 1 (контрольной) группы. Под влиянием разра- ботанной КГМ у крыс 3 группы по сравнению с крысами 2 группы, которые содержались на диете Стефана, обнаружили вероятный рост содержания кислой $(5,13 \pm 0,20$

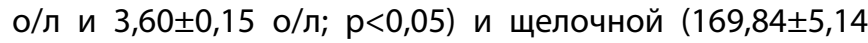
$\mathrm{j} / л$ и $148,21 \pm 6,33 \mathrm{j} / л ; p<0,05)$ фосфатаз, что обусловило уменьшение индекса минерализации $(33,71 \pm 2,01$ и 41,19 $\pm 0,73 ; p<0,05)$. (табл. 2).

Относительно других биохимических показателей, то по сравнению с показателями 1 (контрольной) группы

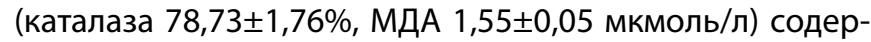
жание крыс на КГД по модели Стефана и по разработанной КГМ приводит кдостоверному уменьшению активности антиоксидантного фермента каталазы $(58,43 \pm 1,71 \%$

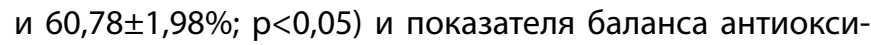
дантных и проксидантных систем индекса АПИ, а также

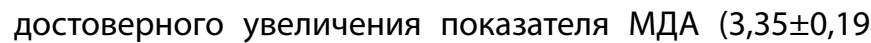

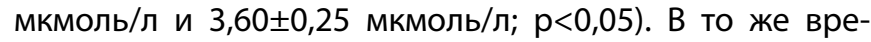
мя, показатели крыс 2 и 3 групп не имеют достоверной разницы между собой Анализ полученных результатов активности ферментов АСТ и АЛТ, которые являются показателями состояния печени и почек, позволил установить достоверное $(p<0,05)$ повышение содержания этих ферментов в сыворотке крыс 2 и 3 групп по сравнению с крысами 1 (контрольной) группы в сыворотке крыс 3 группы по сравнению с показателем крыс 2 группы выявлено достоверное $(p<0,05)$ повышение содержания $\mathrm{ACT}$, который является определенным показателем состояния печени и почек, что некоторым образом отражает влияние на них разработанной модели (см. табл. 2).

Гистологические исследования печени и почек у крыс 3 группы, которые находились на разработанной КГМ, показали определенные изменения обмена воды в исследуемых органах, вероятно, за счет незначительных 


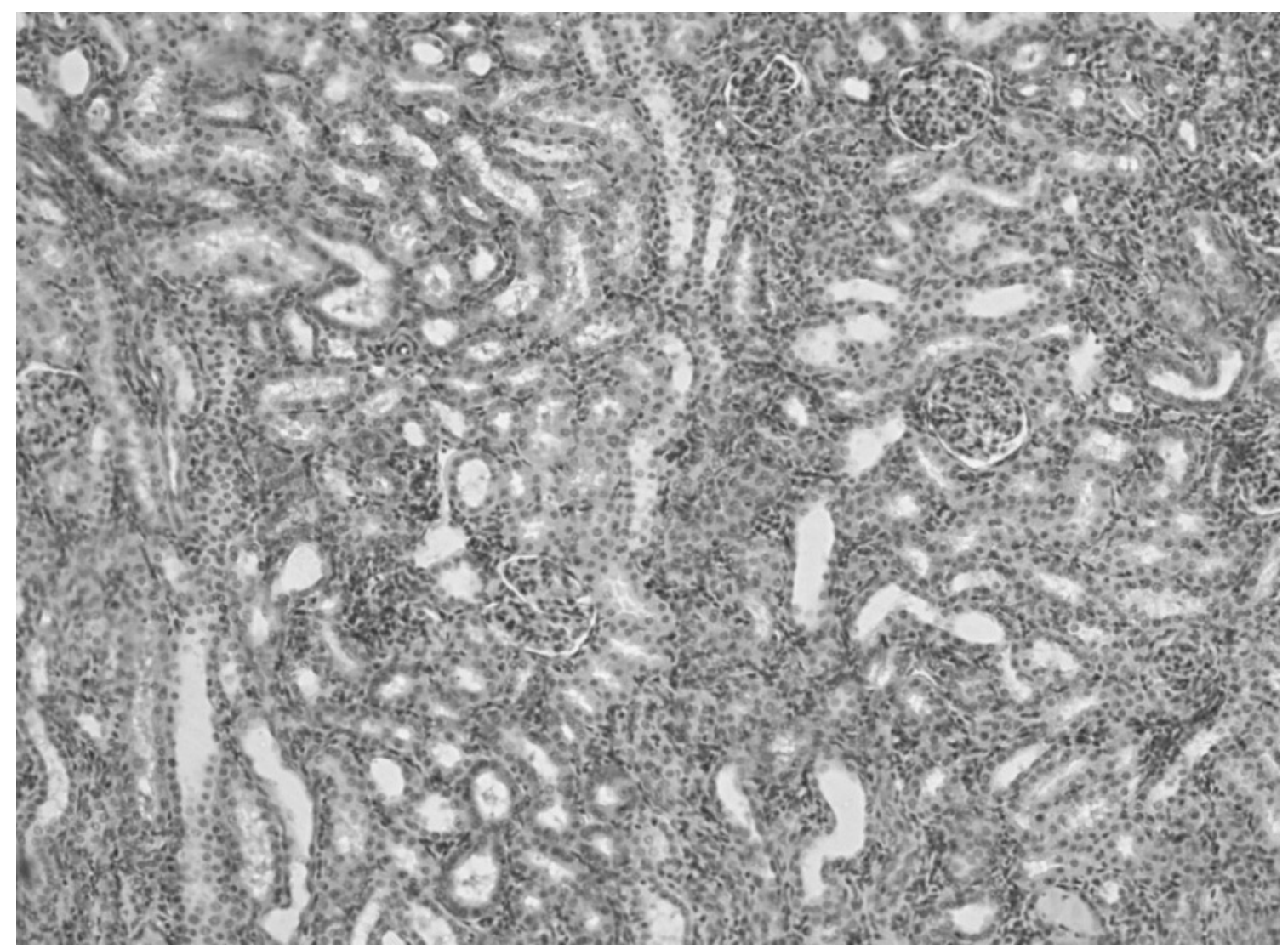

Рис. 4. Печень крысы, которая удерживалась на КГМ по разработанному способу. Гепатоциты с увеличенными сочными ядрами. Клетки Купфера набухшие. Окраска гематоксилином и эозином. Увеличение ${ }^{*} 100$

дистрофических процессов в них. Макроскопическое исследование печени подопытных крыс не определило внешних изменений: поверхность печени гладкая, блестящая, фиброзная капсула прозрачная, передний край острый. При микроскопическом исследовании дольковая структурная организация печени сохранена (рис. 4).

Сосуды триад и центральная вена тонкостенные умеренного кровенаполнения. Гепатоциты упакованы в балки, размеры гепатоцитов средние, хотя существует различие в их размерах в пределах физиологических колебаний. Отдельные гепатоциты двухъядерные. Наружная мембрана гепатоцитов тонкая. Ядра в гепатоцитах увеличенных размеров сочно окрашены, однородной структуры. Цитоплазма гепатоцитов неравномерно окрашена, зернистая по структуре. Межбалочные пространства несколько расширены, Купферовые клетки набухшие, ядра их округло-овальной формы (см. рис. 4).

Почки подопытных крыс 3 группы при макроскопическом исследовании извне не изменены, поверхность гладкая, ткань почки коричнево-красного цвета, лохан- ки небольших размеров. Капсула почки прозрачная, плотная (рис. 5).

При микроскопическом исследовании в коре почек почечные тельца округлой формы, распределены достаточно равномерно. Клубочки капилляров округлой формы, эндотелиоциты набухшие, цитоплазма некоторых из них с вакуолями. Боуменовое пространство незначительно расширенр, внешняя мембрана клубочков утолщена за счет отечного разрыхление Извилистые канальцы коркового вещества обычной округлой формы, с расширенным просветом, эпителиоциты канальцев набухшие, ядра в них смещены к центру. Определяются вакуоли в цитоплазме. Интерстициальные перегородки тонкие, их составляющие волокна разрыхлены, фибробласты с набухшими ядрами. В мозговом веществе канальцы обычной формы, эпителиоциты набухшие, ядра их округлые. Интерстициальные перегородки расширены, инфильтрированы лимфоидными элементами (см. рис. 5).

Исследования гомогенатов костной ткани нижней и верхней челюстей крыс выявило достоверное сни- 
Таблица 3. Биохимические показатели костной ткани челюстей крыс

\begin{tabular}{|l|l|l|l|}
$\begin{array}{l}\text { Показатель } \\
\text { Группа }\end{array}$ & $\begin{array}{l}\text { Крысы 1 (контрольной) } \\
\text { группы (п=10) }\end{array}$ & Крысы 2 группы (п=9) & Крысы 3 группы (п=9) \\
\hline Р (ммоль/Кг) & $8,75 \pm 0,19$ & $8,01 \pm 0,09 Ф$ & $6,47 \pm 0,20$ \\
\hline Са (ммоль/Кг) & $11,62 \pm 0,60$ & $9,06 \pm 0,364$ & $7,36 \pm 0,48$ \\
\hline ЛФ (О/Кг) & $79,41 \pm 3,01^{*}$ & $108,51 \pm 4,84$ & $115,05 \pm 0,55$ \\
\hline КФ (О/Кг) & $2,76 \pm 0,07^{*}$ & $4,04 \pm 0,26<$ & $6,18 \pm 0,42$ \\
\hline ЩФ/КФ (О/Кг) & $28,69 \pm 0,36^{*}$ & $25,11 \pm 1,16>$ & $19,40 \pm 1,28$ \\
\hline МДА (мКмОль/Кг) & $3,45 \pm 0,24^{*}$ & $6,20 \pm 0,19 \Phi$ & $7,11 \pm 0,35$ \\
\hline Каталаза (\%) & $72,30 \pm 1,84^{*}$ & $52,42 \pm 1,22$ & $50,80 \pm 2,11$ \\
\hline АПИ & 20,95 & 8,45 & 7,14 \\
\hline
\end{tabular}

Таблица 4. Биохимические показатели десен крыс

\begin{tabular}{|l|l|l|l|}
\hline $\begin{array}{l}\text { Показатель } \\
\text { Группа }\end{array}$ & $\begin{array}{l}\text { Крысы 1 (контрольной) группы } \\
\left(\begin{array}{l}\Pi=10)\end{array}\right.\end{array}$ & Крысы 2 группы (п=9) & Крысы 3 группы (п=9) \\
\hline КФ (О/Кг) & $1,32 \pm 0,12^{*}$ & $1,64 \pm 0,14$ & $2,15 \pm 0,114$ \\
\hline ЛФ (О/Кг) & $51,09 \pm 2,20^{*}$ & $46,00 \pm 1,21$ & $36,12 \pm 2,474$ \\
\hline МДА (мКмоль/Кг) & $3,21 \pm 0,19^{*}$ & $6,09 \pm 0,23$ & $6,65 \pm 0,24$ \\
\hline Каталаза (\%) & $71,82 \pm 1,74^{*}$ & $54,58 \pm 1,56$ & $50,18 \pm 1,44$ \\
\hline АПІ & $22,71 \pm 1,08^{*}$ & $9,03 \pm 0,21$ & $7,58 \pm 0,20$ \\
\hline
\end{tabular}

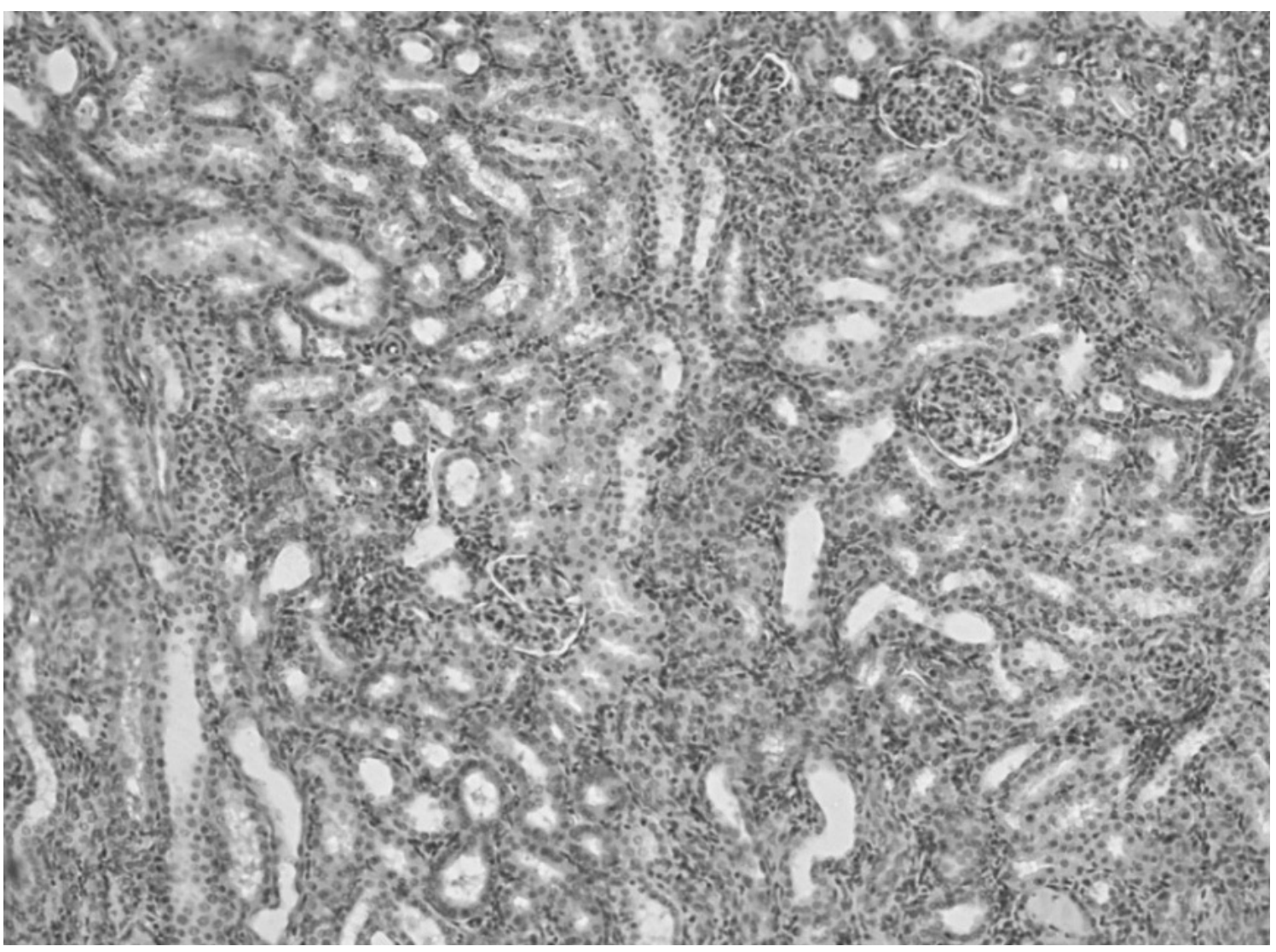

Рис. 5. Почка крысы, которая удерживалась на КГМ по разработанному способу. Округлые капиллярные клубочки, несколько расширенное боуменовое пространство. Окраска гематоксилином и эозином. Увеличение * 100 
жение содержания Са под влиянием разработанной КГМ - 7,36 0,48 ммоль/кг по сравнению с диетой Стефана - 9,06 $\pm 0,36$ ммоль/кг ( $<<0,05)$, снижение содержания P $(6,47 \pm 0,20$ ммоль/кг и 8,01=1=0,09 ммоль/кг; $р<0,05)$, увеличение содержания кислой фосфатазы $(6,18 \pm 0,42$ Л/

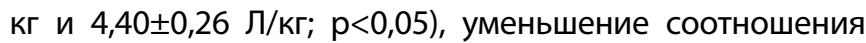
ЩФ и КФ, то есть индекса минерализации $(19,40 \pm 1,28 \mathrm{~A} /$

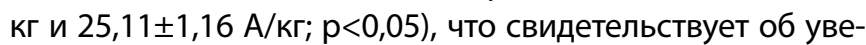
личении активности процессов резорбции костной ткани челюстей. Достоверное $(p<0,05)$ повышение уровня МДА и снижение активности каталазы в группах крыс, которые находились на КГМ, указывают на снижение САОЗ (табл. 3)

Воспроизведение кариеса по разработанной КГМ приводит к достоверным ( $<<0,05)$ изменениям биохимических показателей гомогенатов десен у крыс, которые характеризуют состояние воспалительных процессов и баланс САОЗ, по сравнению с таковыми относительно крыс 1 группы. У крыс 3 группы определили достоверные увеличения КФ - 2,15 $\pm 0,11$ о/кг и уменьшение ЛФ - 36,12 2 ,47 о/кг, уменьшение активности катала-

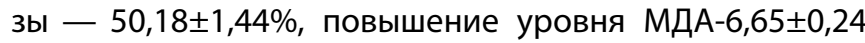
мкмоль/кг. Последние два показателя были хуже, чем показатели крыс 2 группы, которые находились на кариесогенном рационе Стефана, но недостоверно (табл. 4).

Таким образом, результаты экспериментальных исследований обосновывают разработанную модель экспериментального воспроизведения кариеса зубов у крыс, которая основывается на применении сбалансированной КГД с достаточным количеством прямых углеводов и дополнительном введении антибиотика аминогликозидного ряда гентамицина в бактериостатической концентрации.

\section{ЛИТЕРАТУРА}

1. 05.04-19Р2.95П Прозрачные зубоврачебные составы // РЖ 19Р-2. Технология производства продуктов бытовой химии. Парфюмерия и косметика.2005.— № 4.

2. Гладышева, 0.М. Одонтогенные абсцессы и флегмоны челюстно-лицевой области по материалам II хирургического отделения / 0.М. Гладышева // Бюллетень Северного государственного медицинского университета. — 2014. — № 1(32). — С. 75-76.

3. Зырянов, Б.Н. Роль состава и свойств ротовой жидкости в механизмах развития кариеса зубов у рабочих производства антибиотиков / Б.Н. Зырянов, А.В. Лебедев, Т.В. Притыкина // Институт стоматологии.— 2007.— № 2(35).- С. 60-61.

4. Костюк, 3.М. Изучение стоматологической и соматической заболеваемости у спортсменов-гребцов 15-18 лет / 3.М. Костюк, А.Г. Пономарева, М.А. Саркисян // Вестник спортивной науки. - 2014. — № 5.- С. 37-40.

5. Кулакова, Е.В. Эндогенные антимикробные полипептиды - факторы неспецифической защиты организма / Е.В. Кулакова, В.М. Елизарова, А.Н. Пампура // Российский стоматологический журнал. - 2012.—№ 6. - С. 42-45.

6. Плещева, В.Ю. Влияние приема антибиотиков на формирование эмали зубов / В.Ю. Плещева // Молодая наука — практическому здравоохранению: материалы 92-й итоговой научно-практической конференции студентов, ординаторов, аспирантов, молодых ученых (до 35 лет) ПГМУ имени академика Е.А. Вагнера, Пермь, 15-16 апреля 2019 года / Пермский государственный медицинский университет имени академика Е.А. Вагнера.— Пермь: Б. и., 2019.- - . 145-147.

7. Успенский, Ю.П. Первый в России опыт использования «Гевискона» в лечении гастроэзофагеальной рефлюксной болезни / Ю.П. Успенский, И.Г. Пахомова, Е.И. Ткаченко // РМЖ.-2007.- Т. 15.— №22.-С. 1639-1642.

8. Шумилович, Б.Р. Клинико-лабораторные аспекты эффективности применения газообразного озона при повторном эндодонтическом лечении зубов / Б.Р. Шумилович, Я.Ю. Сидоров, Р.В. Селин // Системный анализ и управление в биомедицинских системах. — 2015.— Т. 14.— № 4.— С. 693-698.

( Кантария Гванца Отариевна ( gvantsa_15@mail.ru ), Кабытова Мария Викторовна ( mashan.hoi@mail.ru ), Онищенко Любовь Федоровна ( onishchenko_If@mail.ru ), Огонян Елена Александровна ( ogonyan111@mail.ru ).

Журнал «Современная наука: актуальные проблемы теории и практики» 